\title{
Peran Efikasi Diri dan Dukungan Sosial Teman Sebaya Terhadap Penyesuaian Diri Mahasiswa Tahun Pertama Program Studi Pendidikan Dokter Fakultas Kedokteran Universitas Udayana
}

\author{
Ida Ayu Gede Hutri Dhara Sasmita dan I Made Rustika \\ Program Studi Psikologi, Fakultas Kedokteran, Universitas Udayana \\ idaayuhutri@gmail.com
}

\begin{abstract}
Abstrak
Penyesuaian diri merupakan aspek mental penting yang sangat menentukan keberhasilan seseorang dalam menghadapi berbagai permasalahan dalam hidupnya. Aspek mental ini sangat berkaitan dengan keyakinan seseorang terhadap kemampuan diri dalam mengendalikan berbagai rintangan dan menggunakan potensi diri. Disamping itu, aspek mental ini juga sangat berkaitan dengan respon positif dari lingkungan.Tujuan penelitian ini adalah mengetahui peran efikasi diri dan dukungan sosial teman sebaya terhadap penyesuaian diri mahasiswa tahun pertama Program Studi Pendidikan Dokter Fakultas Kedokteran Universitas Udayana.

Subjek dalam penelitian ini adalah 137 orang mahasiswa tahun pertama Program Studi Pendidikan Dokter Fakultas Kedokteran Universitas Udayana. Instrumen penelitian ini adalah skala efikasi diri, skala dukungan sosial teman sebaya dan skala penyesuaian diri.

Hasil analisis regresi berganda menunjukkan $\mathrm{R}=0,605(\mathrm{~F}=38,776$; $\mathrm{p}<0,05)$ dengan demikian dapat disebutkan bahwa efikasi diri dan dukungan sosial teman sebaya secara bersama-sama berperan terhadap penyesuaian diri. Koefisien determinasi sebesar 0,367 sehingga sumbangan efektif efikasi diri dan dukungan sosial teman sebaya terhadap penyesuaian diri sebesar $36,7 \%$. Koefisien beta terstandarisasi efikasi diri sebesar $0,457 \quad(t=5,935 ; p<0,05)$ menunjukkan efikasi diri berperan terhadap penyesuaian diri. Koefisien beta terstandarisasi dukungan sosial teman sebaya sebesar $0,242(\mathrm{t}=3,141 ; \mathrm{p}<0,05)$ menunjukkan dukungan sosial teman sebaya berperan terhadap penyesuaian diri.
\end{abstract}

Kata kunci: efikasi diri, dukungan sosial teman sebaya, penyesuaian diri, mahasiswa tahun pertama

\begin{abstract}
Adjustment is an important mental aspects that determine a person's success in dealing with various problems in his life. The mental aspect is related to one's belief in the ability to control various obstacles and use your own potential. In addition, the mental aspect is also strongly associated with a positive response from the environment.The purpose of this research is to find out the role of self efficacy and peers social support toward personal adjustment in Medical School Udayana University.

Subjects in this research were 137 first-year students Medical School Udayana University. The instruments in this research were self-efficacy scale, peers social support scale and personal adjustment scale.

The result of multiple regression analysis shows $\mathrm{R}=0,605(\mathrm{~F}=38,776$; $\mathrm{p}<0,05)$ thus it can be stated that both selfefficacy and peers social support together contributes to personal adjustment. Determination coefficient $=0,367$, which means the effective contribution of self-efficacy and peers social support to personal adjustment is $36,7 \%$. Standardized beta coefficient of self-efficacy is $0,457(\mathrm{t}=5,935 ; \mathrm{p}<0,05)$ thus it can be stated self-efficacy contribute to personal adjustment. Standardized beta coefficient of peers social support is $0,242(t=3,141 ; p<0,05)$ thus it can be stated peers social support contribute to personal adjustment.
\end{abstract}

Keywords: self-efficacy, peers social support, personal adjustment, first-year student. 


\section{LATAR BELAKANG}

Dalam melewati setiap tahap perkembangan, individu akan menghadapi masa transisi. Masa transisi dalam tahap perkembangan terjadi ketika anak-anak berkembang menjadi remaja, kemudian berkembang lagi menjadi orang dewasa. Selain transisi dari tahap perkembangan, masa transisi individu juga terjadi di masa sekolahnya. Transisi sekolah adalah perpindahan siswa dari sekolah yang lama ke sekolah baru yang lebih tinggi tingkatannya. Mulai dari sekolah dasar menuju sekolah menengah pertama, sekolah menengah atas, hingga menuju perguruan tinggi (Santrock, 2007).

Transisi siswa dari Sekolah Menengah Atas (SMA) menuju Perguruan Tinggi merupakan masa transisi sekolah yang lebih kompleks dibandingkan masa transisi sekolah sebelumnya karena masa transisi siswa dari Sekolah Menengah atas (SMA) menuju Perguruan Tinggi seringkali mengakibatkan perubahan dan stres (Santrock, 2007). Permasalahan yang timbul sebagai akibat dari masa transisi dari Sekolah Menengah Atas (SMA) menuju Perguruan Tinggi lebih banyak dialami oleh mahasiswa, terutama mahasiswa yang berada pada tahun pertama perkuliahan.

Masalah yang seringkali dialami oleh mahasiswa tahun pertama adalah pergeseran posisi atau yang disebut dengan top-dog phenomenon, yaitu pergeseran posisi sebagai siswa senior di Sekolah Menengah Atas (SMA) menjadi mahasiswa baru di Perguruan Tinggi (Santrock, 2007). Selain itu, perbedaan sifat pendidikan yang dilihat dari kurikulum, disiplin, hubungan antara dosen dengan mahasiswa, penyesuaian dalam hubungan sosial, masalah ekonomi serta pemilihan bidang studi dan jurusan, perubahan gaya hidup, perubahan gaya belajar dari Sekolah Menengah Atas (SMA) ke Perguruan Tinggi, tugas-tugas perkuliahan, target pencapaian nilai dan problem-problem akademik lainnya menjadi penyebab kesulitan mahasiswa dalam tahun pertama perkuliahannya (Gunarsa \& Gunarsa, 2000; Santrock, 2003).

Berdasarkan hasil studi pendahuluan yang dilakukan oleh peneliti terhadap 33 orang mahasiswa tahun pertama Program Studi Pendidikan Dokter Fakultas Kedokteran Universitas Udayana diketahui bahwa mahasiswa mengalami sejumlah masalah saat memasuki dunia perkuliahan. Masalah yang dialami mahasiswa seperti kesulitan mengikuti sistem ujian blok, sulit memahami pelajaran, sulit mengatur waktu, kurang mampu berkonsentrasi, kurang mampu membuat jadwal kegiatan, dan kesulitan menjalin hubungan pertemanan sehingga hal tersebut menimbulkan dampak seperti waktu tidur berkurang, sering merasa kesepian, mengalami masalah kesehatan, berkurangnya minat untuk mengikuti pelajaran, waktu bersama keluarga berkurang, gagal menempuh ujian blok, mengeluh, dan menangis. Selain itu, dalam studi pendahuluan tersebut diketahui bahwa beberapa mahasiswa mampu mengatasi kesulitan-kesulitan yang ditemui dengan cara mengatur waktu dengan membuat jadwal kegiatan sehari- hari dan menjalin hubungan pertemanan dengan banyak orang, tetapi beberapa mahasiswa lainnya merasa kurang mampu mengatasi kesulitan yang dihadapinya (Sasmita, 2014).

Sejalan dengan studi pendahuluan yang dilakukan oleh peneliti, berbagai hasil penelitian mengenai transisi mahasiswa tahun pertama di Fakultas Kedokteran telah banyak dilaporkan oleh beberapa peneliti sebelumnya. Hasil penelitian Maulana, Soleha, Saftarina, Siagian (2014) yang dilakukan pada 92 mahasiswa tahun pertama Fakultas Kedokteran Universitas Lampung terdapat 4 (4,3\%) mahasiswa mengalami stres ringan, $66(71,7 \%)$ mahasiswa mengalami stres sedang, dan $22 \quad(23,9 \%)$ mahasiswa mengalami stres berat. Hasil penelitian Suganda (2013) menunjukkan dari 422 mahasiswa tahun pertama Fakultas Kedokteran Universitas Sumatra Utara terdapat 15 orang $(3,6 \%)$ mengalami stres ringan, 365 orang $(86,5 \%)$ mengalami stres sedang, dan 42 orang (10\%) mengalami stres berat. Hasil penelitian Shah, Hasan, Malik, \& Sreeramareddy (2010) \& Abdulghani (2008) menunjukkan bahwa tuntutan yang dialami oleh mahasiswa pendidikan dokter seperti adanya ekspektasi yang tinggi dari orangtua, frekuensi ujian yang lebih sering terjadi dibandingkan fakultas lainnya, dan waktu yang cepat untuk menyelesaikan kurikulum akademik seringkali menyebabkan waktu tidur yang berkurang, kecemasan tentang masa depan, kesepian, ketidakpuasan dalam pengajaran materi perkuliahan, penurunan prestasi akademik, penurunan konsentrasi belajar, dan penurunan daya ingat.

Perubahan dan tuntutan yang muncul pada masa transisi sekolah dari Sekolah Menengah Atas (SMA) menuju Perguruan Tinggi menuntut mahasiswa untuk dapat melakukan penyesuaian diri. Menurut Muharomi (2012) kemampuan penyesuaian diri merupakan hal yang harus dimiliki oleh mahasiswa. Hal ini berguna untuk mencegah terjadinya goncangan psikis dan memberikan kemudahan bagi mahasiswa dalam menjalani kehidupan yang baru, terutama di lingkungan kampus.

Menurut Schneider (1964) penyesuaian diri merupakan suatu proses yang mencakup respon-respon mental dan tingkah laku individu untuk mampu mengatasi kebutuhan, ketegangan, konflik dan frustrasi. Usaha tersebut bertujuan untuk memperoleh keselarasan dan keharmonisan antara tuntutan dalam diri dan tuntutan lingkungan. Tujuh aspek penyesuaian diri menurut Schneider (1964) terdiri dari a) mengontrol emosi yang berlebihan, b) meminimalkan mekanisme pertahanan diri, c) mengurangi rasa frustrasi, d) berpikir rasional dan mampu mengarahkan diri, e) kemampuan untuk belajar, f) memanfaatkan pengalaman masa lalu, dan g) sikap realistis dan objektif.

Mahasiswa yang mempunyai kemampuan penyesuaian diri yang baik mengalami sedikit tekanan, sedangkan mahasiswa yang mempunyai kemampuan penyesuaian diri yang buruk merasa mendapat tekanan dan 
cenderung berdampak pada perilaku defensif (Hurlock, 1980). Berdasarkan uraian diatas, timbul pertanyaan dari peneliti mengapa beberapa mahasiswa mampu menyesuaikan diri sedangkan beberapa mahasiswa lainnya kurang mampu menyesuaikan diri?

Menurut Schneiders (1964) kemampuan menyesuaikan diri berkaitan dengan proses pembentukan keyakinan. Schneiders menyebutkan bahwa kondisi psikologis merupakan salah satu faktor yang mempengaruhi penyesuaian diri. Kondisi psikologis meliputi keadaan mental individu yang sehat, individu yang memiliki mental yang sehat mampu melakukan pengaturan terhadap dirinya sendiri dalam perilakunya secara efektif. Menurut Bandura (dalam Smet, 1994) untuk mengatur perilaku akan dibentuk atau tidak, individu tidak hanya mempertimbangkan informasi dan keyakinan tentang keuntungan dan kerugian, tetapi juga mempertimbangkan sampai sejauh mana individu mampu mengatur perilaku tersebut, kemampuan ini disebut dengan efikasi diri.

Menurut Bandura (1997), efikasi diri adalah keyakinan akan kemampuan diri seseorang dalam mengorganisasikan dan melakukan serangkaian tindakan yang sesuai untuk mencapai suatu hasil yang diharapkan. Keyakinan tersebut merupakan rasa percaya terhadap kemampuan diri sehingga mampu mendorong seseorang untuk meraih segala sesuatu yang diinginkannya. Aspek efikasi diri menurut Bandura (1997) terdiri dari a) level, b) generality, dan c) strength. Mahasiswa yang memiliki keyakinan yang kuat terhadap kemampuan yang dimiliki akan lebih gigih berusaha dan tidak mudah menyerah meskipun menghadapi berbagai kesulitan dan rintangan.

Di sisi lain, salah satu faktor yang dapat membantu pelajar dalam mengatasi masalah yang berhubungan dengan kehidupan kuliah adalah dukungan sosial (Lepore dalam Taylor, Peplau, \& Sears, 2000). Hal ini sejalan dengan pendapat Effendi \& Tjahjono (1999) yang menyatakan bahwa dukungan sosial berperan penting dalam memelihara keadaan psikologis individu yang mengalami tekanan sehingga menimbulkan pengaruh positif yang dapat mengurangi goncangan psikologis. Dukungan sosial memang bisa berasal dari mana saja (Sarafino \& Smith, 2010), salah satunya adalah teman sebaya. Teman sebaya atau yang lebih dikenal dengan sebutan peer merupakan kelompok individu yang memiliki usia atau tingkat kematangan yang kurang lebih sama. Teman sebaya merupakan sumber dukungan emosional penting sepanjang transisi masa remaja. Intensitas dan waktu yang dihabiskan bersama teman lebih besar pada masa remaja dibandingkan waktu lain dalam rentang kehidupan (Papalia, Old, \& Feldman, 2008).

Dukungan sosial teman sebaya adalah dukungan yang diberikan kepada individu oleh kelompok sebayanya berupa kenyamanan secara fisik dan psikologis sehingga individu tersebut merasa dicintai, diperhatikan, dihargai sebagai bagian dari kelompok sosial. aspek dukungan sosial teman sebaya pada penelitian ini mengacu pada aspek dukungan sosial dari Sarafino \& Smith (2010) yang membagi dukungan sosial kedalam empat aspek, yaitu a) emotional or esteem support, b) tangible or instrumental support, c) informational support, dan d) companionship support.

Pada saat individu mengalami goncangan psikologis akibat rendahnya kemampuan dalam menghadapi perubahan dan tuntutan dalam perkuliahan, teman sebaya dapat memberikan dukungan dengan memberikan kenyamanan fisik seperti menemaninya disaat sedih, membantunya mengerjakan tugas yang sulit, dan memberikan pertolongan dengan melakukan suatu pekerjaan. Selain kenyamanan fisik, teman sebaya dapat memberikan kenyamanan psikologis dengan cara membuat kondisi agar seseorang menjadi bagian dari suatu kelompok sosial. Dukungan tersebut dapat berupa empati, kasih sayang, perhatian, penghargaan positif, dan nasihat. Kondisi seperti itu akan memberikan individu rasa penerimaan, kehangatan dan pengertian sehingga dapat membantu individu untuk meningkatkan kemampuan dalam menghadapi masalah secara efektif.

Berdasarkan uraian di atas, tujuan dari penelitian ini adalah mengetahui peran efikasi diri dan dukungan sosial teman sebaya terhadap penyesuaian diri mahasiswa tahun pertama Program Studi Pendidikan Dokter Fakultas Kedokteran Universitas Udayana.

\section{METODE PENELITIAN}

\section{Variabel dan definisi operasional}

Dalam penelitian ini efikasi diri dan dukungan sosial teman sebaya sebagai variabel bebas dan penyesuaian diri sebagai variabel tergantung.

Definisi operasional dari penyesuaian diri adalah proses yang melibatkan kemampuan individu untuk dapat mengatasi kebutuhan baik yang berasal dari dalam diri individu maupun dari lingkungan sekitar, mengatasi ketegangan, frustrasi, serta konflik yang dihadapinya untuk mencapai hubungan yang baik dengan orang lain dan lingkungan sekitar. Penyesuaian diri diukur dengan skala penyesuaian diri yang disusun berdasarkan aspek-aspek penyesuaian diri yang dikemukakan oleh Schneider, yaitu mengontrol emosi yang berlebihan, meminimalkan mekanisme pertahanan diri, mengurangi rasa frustrasi, berpikir rasional dan mampu mengarahkan diri, kemampuan untuk belajar, memanfaatkan pengalaman masa lalu dan sikap realistis dan objektif.

Definisi operasional dari efikasi diri adalah keyakinan akan kemampuan diri seseorang dalam mengorganisasikan dan melakukan serangkaian tindakan dengan menggunakan keterampilan yang dimiliki untuk 
mencapai hasil yang diharapkan. Efikasi diri diukur dengan skala efikasi diri yang disusun berdasarkan aspek-aspek efikasi yang dikemukakan oleh Bandura yaitu, level, generality dan strength.

Definisi operasional dari dukungan sosial teman sebaya adalah dukungan yang diberikan kepada individu oleh kelompok sebayanya berupa kenyamanan secara fisik dan psikologis sehingga individu tersebut merasa dicintai, diperhatikan, dihargai sebagai bagian dari kelompok sosial. Dukungan sosial teman sebaya diukur dengan skala dukungan sosial yang disusun berdasarkan aspek-aspek dukungan sosial yang dikemukakan oleh Sarafino \& Smith yaitu, emotional or esteem support, tangible or instrumental support, informational support, dan companionship support.

\section{Responden}

Populasi dalam penelitian ini adalah keseluruhan mahasiswa semester II Program Studi Pendidikan Dokter Fakultas Kedokteran Universitas Udayana yang berjumlah 257 orang. Sampel diambil dari populasi dengan menggunakan teknik simple random sampling, yaitu pengambilan anggota sampel dari populasi dilakukan secara acak tanpa memperhatikan strata yang ada dalam populasi tersebut (Sugiyono, 2013). Jumlah skala yang kembali sebanyak 157 skala, namun hanya 149 skala yang memenuhi syarat kelengkapan untuk dapat digunakan dalam analisis data. Pada proses uji asumsi, peneliti membuang 12 outlier yang menyebabkan data tidak normal sehingga dapat disebutkan jumlah subjek yang memenuhi syarat dalam penelitian ini sebanyak 137 orang.

\section{Tempat penelitian}

Pengambilan data try out dilakukan di Fakultas Kedokteran Universitas Udayana dengan menggunakan Program Studi Ilmu Keperawatan sebagai subjek try out. Pengambilan data setelah try out dilakukan di Fakultas Kedokteran Universitas Udayana dengan menggunakan Program Studi Pendidikan Dokter sebagai subjek.

\section{Alat ukur}

Alat ukur dalam penelitian ini peneliti menggunakan tiga skala yaitu skala efikasi diri, skala dukungan sosial teman sebaya, dan skala penyesuaian diri. Skala efikasi diri dalam penelitian ini diadaptasi dari skala efikasi diri dari Rustika (2014) yang telah teruji validitas dan reliabilitasnya. Koefisien reliabilitas skala efikasi diri dari Rustika (2014) adalah sebesar 0,840 sedangkan untuk uji validitas dengan menggunakan teknik analisis faktor konfirmatori menunjukkan skala tersebut memiliki unidimensionalitas sehingga dapat disebutkan bahwa skala tersebut valid. Skala efikasi diri dari Rustika (2014) berjumlah 20 item dengan berdasar pada aspek-aspek efikasi diri yang dikemukakan oleh Bandura yaitu level, strenght, dan generality. Skala dukungan sosial teman sebaya dan skala penyesuaian diri ditulis sendiri oleh peneliti dengan bantuan professional judgement. Skala dukungan sosial teman sebaya berjumlah 38 item dengan berdasar pada aspek-aspek dukungan sosial teman sebaya yang dikemukakan oleh Sarafino \& Smith yaitu emotional or esteem support, tangible or instrumental support, informational support, dan companionship support. Skala penyesuaian diri berjumlah 39 item dengan berdasar pada aspek-aspek penyesuaian diri yang dikemukakan oleh Schneider yaitu mengontrol emosi yang berlebihan, meminimalkan mekanisme pertahanan diri, mengurangi rasa frustrasi, berpikir rasional dan mampu mengarahkan diri, kemampuan untuk belajar, memanfaatkan pengalaman masa lalu, dan sikap realistis dan objektif.

\section{Teknik pengumplan data}

Metode pengumpulan data dalam penelitian ini adalah dengan menggunakan skala. Peneliti memberikan skala yang disusun dengan menyediakan pilihan jawaban, sehingga responden hanya memberikan tanda pada jawaban yang dipilih. dalam penelitian ini peneliti menggunakan tiga skala yaitu skala efikasi diri, skala dukungan sosial teman sebaya, dan skala penyesuaian diri. Pengumpulan data dalam penelitian ini dilaksanakan pada tangal 16 Maret 2015 di Program Studi Pendidikan Dokter Fakultas Kedokteran Universitas Udayana. Setelah data terkumpul, peneliti melakukan skoring untuk keperluan analisis data.

\section{Teknik analisis data}

Teknik analisis data yang digunakan dalam penelitian ini adalah analisis regresi ganda. Dalam penelitian ini analisis regresi ganda digunakan untuk mengetahui hubungan dua variabel bebas yaitu efikasi diri dan dukungan sosial teman sebaya terhadap variabel tergantung yaitu penyesuaian diri. Analisis data dalam penelitian ini menggunakan program SPSS windows versi 15 .

\section{HASIL PENELITIAN}

Berdasarkan hasil uji validitas dan reliabilitas yang dilakukan, untuk skala dukungan sosial teman sebaya terdapat 38 item yang valid dan 2 item yang gugur dengan rentang koefisien validitas dari 0,296 sampai 0,645 dan koefisien reliabilitas sebesar 0,926 pada item yang valid. skala penyesuaian diri terdapat 39 item yang valid dan 17 item yang gugur dengan rentang koefisien validitas dari 0,266 sampai 0,582 dan koefisien reliabilitas sebesar 0,900 pada item yang valid. 
Berdasarkan analisis data, peneliti merangkum deskripsi subjek penelitian dalam sebuah tabel. Untuk hasil selengkapnya dapat dilihat pada tabel di bawah ini.

Deskripsi Subjek Penelitian Berdasarkan Jenis Kelamin

\begin{tabular}{ccc}
\hline Jenis Kelamin & Jumlah Mahasiswa & Persentase $(\%)$ \\
\hline Laki-laki & 51 Orang & $37,2 \%$ \\
\hline Perempuan & 86 Orang & $62,8 \%$ \\
\hline
\end{tabular}

Deskripsi Subjek Penelitian Berdasarkan Asal Sekolah Menengah Atas/Sederajat

\begin{tabular}{ccc}
\hline Daerah & Jumlah Mahasiswa & Persentase \\
\hline Bali & 103 Orang & $75,2 \%$ \\
\hline Luar Bali & 31 Orang & $22,6 \%$ \\
\hline Luar Negeri & 3 Orang & $2,2 \%$ \\
\hline
\end{tabular}

Berdasarkan hasil skor yang telah didapatkan diperoleh gambaran secara umum mengenai kondisi efkasi diri, dukungan sosial teman sebaya dan penyesuaian diri mahasiswa tahun pertama Program Studi Pendidikan Dokter Fakultas Kedokteran Universitas Udayana. untuk hasil selengkapnya dapat dilihat pada tabel di bawah ini

\begin{tabular}{|c|c|c|c|c|c|c|c|c|}
\hline \multicolumn{9}{|c|}{ Deskripsi Data Penelitian } \\
\hline Variabel & $\mathrm{N}$ & $\begin{array}{c}\text { Mean } \\
\text { Teoritis }\end{array}$ & $\begin{array}{c}\text { Mean } \\
\text { Empiris }\end{array}$ & $\begin{array}{c}\text { Std } \\
\text { Deviasi } \\
\text { Teoritis }\end{array}$ & $\begin{array}{c}\text { Std } \\
\text { Deviasi } \\
\text { Empiris }\end{array}$ & $\begin{array}{l}\text { Sebaran } \\
\text { Teoritis }\end{array}$ & $\begin{array}{l}\text { Sebaran } \\
\text { Empiris }\end{array}$ & Nilai T \\
\hline ED & 137 & 50 & 57,55 & 10 & 4,429 & $20-80$ & $46-69$ & $\begin{array}{c}19,945 \\
(\mathrm{p}=0,000)\end{array}$ \\
\hline DSTS & 137 & 95 & 115,29 & 19 & 7,607 & $38-152$ & $92-134$ & $\begin{array}{c}31,222 \\
(\mathrm{p}=0,000)\end{array}$ \\
\hline PD & 137 & 97,5 & 113,73 & 19,5 & 7,814 & $39-156$ & $87-131$ & $\begin{array}{c}24,312 \\
(\mathrm{p}=0,000)\end{array}$ \\
\hline \multicolumn{9}{|c|}{ Kategorisasi Efikasi Diri } \\
\hline \multirow{2}{*}{\multicolumn{3}{|c|}{$\begin{array}{l}\text { Rentang Nilai } \\
\mathrm{x}=35\end{array}$}} & \multirow{2}{*}{\multicolumn{2}{|c|}{$\begin{array}{c}\text { Kategori } \\
\text { angat rendab }\end{array}$}} & \multirow{2}{*}{\multicolumn{2}{|c|}{ Jumlah }} & \multicolumn{2}{|c|}{ Persentase } \\
\hline \multirow{2}{*}{\multicolumn{3}{|c|}{$\begin{array}{c}\mathrm{X} \leq 35 \\
35<\mathrm{X}<45\end{array}$}} & & & & & \multirow{2}{*}{\multicolumn{2}{|c|}{$\begin{array}{l}0 \% \\
0 \%\end{array}$}} \\
\hline & & & \multicolumn{2}{|c|}{ rendah } & \multicolumn{2}{|r|}{0} & & \\
\hline & \multicolumn{2}{|r|}{ sedang } & \multicolumn{2}{|r|}{45} & \multicolumn{2}{|c|}{$32.9 \%$} \\
\hline \multicolumn{3}{|c|}{$55<\mathrm{X} \leq 65$} & \multicolumn{2}{|r|}{ ting gi } & \multicolumn{2}{|r|}{88} & \multicolumn{2}{|c|}{$64.2 \%$} \\
\hline \multicolumn{3}{|c|}{$65<\bar{X}$} & & angat tinggi & & 4 & & $\%$ \\
\hline
\end{tabular}

Berdasarkan kondisi empiris di atas diketahui bahwa mean empirik variabel efikasi diri lebih besar dari mean hipotetiknya yaitu sebesar 57,55 dengan nilai $t \quad 19,945$ ( $\mathrm{p}=0,000)$. Hal ini menunjukkan bahwa terdapat perbedaan yang signifikan antara mean empiris dan teoritis pada variabel efikasi diri. Rentang skor subjek penelitian antara 46 sampai 69 yang berdasarkan penyebaran frekuensi, 94,16\% subjek berada diatas mean teoritis. Berdasarkan kategorisasi efikasi diri pada tabel di atas menunjukkan bahwa mayoritas efikasi diri subjek yang tergolong tinggi.

\begin{tabular}{cccc}
\multicolumn{4}{c}{ Kategorisasi Dukungan Sosial Teman Sebaya } \\
\hline Rentang Nilai & Kategori & Jumlah & Persentase \\
\hline $\mathrm{X} \leq 66,5$ & sangat rendah & 0 & $0 \%$ \\
\hline $66,5<\mathrm{X} \leq 85,5$ & rendah & 0 & $0 \%$ \\
\hline $85,5<\mathrm{X} \leq 104,5$ & sedang & 10 & $7,3 \%$ \\
\hline $104,5<\mathrm{X} \leq 123,5$ & tinggi & 107 & $78,1 \%$ \\
\hline $123,5<\mathrm{X}$ & sangat tinggi & 20 & $14,6 \%$ \\
\hline
\end{tabular}

Berdasarkan kondisi empiris di atas diketahui bahwa mean empirik variabel dukungan sosial teman sebaya lebih besar dari mean hipotetiknya yaitu sebesar 115,29 dengan nilai t 31,222 ( $\mathrm{p}=0,000)$. Hal ini menunjukkan bahwa terdapat perbedaan yang signifikan antara mean empiris dan teoritis pada variabel dukungan sosial teman sebaya. Rentang skor subjek penelitian antara 92 sampai 134 yang berdasarkan penyebaran frekuensi, 99,27\% subjek berada diatas mean teoritis. Berdasarkan kategorisasi dukungan sosial teman sebaya pada tabel di atas menunjukkan bahwa mayoritas dukungan sosial teman sebaya yang diperoleh subjek tergolong tinggi.

\begin{tabular}{cccc}
\multicolumn{5}{c}{ Kategorisasi Penyesuaian Diri } \\
\hline Rentang Nilai & Kategori & Jumlah & Persentase \\
\hline $\mathrm{X} \leq 68,25$ & sangat rendah & 0 & $0 \%$ \\
\hline $68,25<\mathrm{X} \leq 87,75$ & rendah & 0 & $0 \%$ \\
\hline $87,75<\mathrm{X} \leq 107,25$ & sedang & 28 & $20,5 \%$ \\
\hline $107,25<\mathrm{X} \leq 126,75$ & tinggi & 102 & $74,4 \%$ \\
\hline $126,75<\mathrm{X}$ & sangat tinggi & 7 & $5,1 \%$ \\
\hline
\end{tabular}

Berdasarkan kondisi empiris di atas diketahui bahwa mean empirik variabel penyesuaian diri lebih besar dari mean hipotetiknya yaitu sebesar 113,73 dengan nilai t 24,312 $(p=0,000)$. Hal ini menunjukkan bahwa terdapat perbedaan yang signifikan antara mean empiris dan teoritis pada variabel penyesuaian diri. Rentang skor subjek penelitian antara 87 sampai 131 yang berdasarkan penyebaran frekuensi, 97,08\% subjek berada diatas mean teoritis. Berdasarkan kategorisasi penyesuaian diri pada tabel di atas menunjukkan bahwa mayoritas penyesuaian diri subjek yang tergolong tinggi.

Berdasarkan hasil uji asumsi yaitu uji normalitas diperoleh bahwa ketiga variabel dalam penelitian ini berdistribusi normal. Nilai Asymp.Sig (2-tailed) dari data penyesuaian diri sebesar 0,409; nilai Asymp.Sig (2-tailed) dari data efikasi diri sebesar 0,238; dan nilai Asymp.Sig (2-tailed) dari data dukungan sosial teman sebaya sebesar 0,057. Nilai signifikansi dari ketiga variabel tersebut menunjukkan lebih dari 0,05 maka dapat disimpulkan bahwa variabel penyesuaian diri, efikasi diri, dan dukungan sosial teman sebaya berdistribusi normal. Untuk hasil selengkapnya dapat dilihat pada tabel berikut:

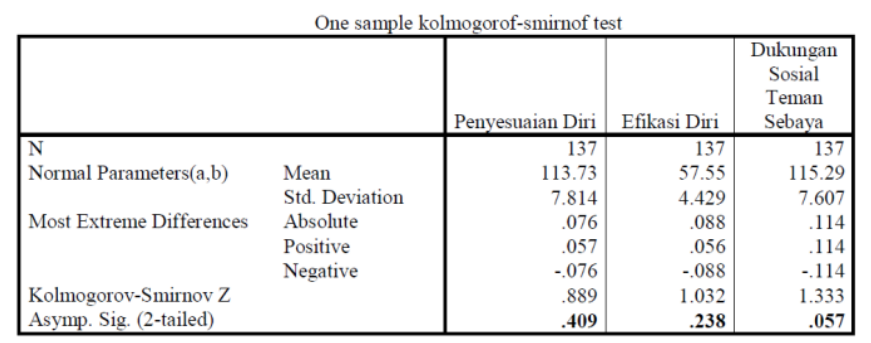

Berdasarkan hasil uji asumsi kedua yaitu uji liniearitas menunjukkan adanya hubungan yang liniear antara penyesuaian diri dengan efikasi diri dengan nilai signifikansi sebesar 0,000. Hasil uji juga menunjukkan hubungan yang liniear antara penyesuaian diri dengan dukungan sosial teman sebaya dengan nilai signifikansi sebesar 0,000. Kedua nilai signifikansi berada dibawah 0,05, sehingga dapat disebutkan terdapat hubungan yang liniear antara penyesuian diri dengan efikasi diri dan dukungan sosial teman sebaya. Untuk hasil selengkapnya dapat dilihat pada tabel di bawah ini:

\begin{tabular}{ccccc}
\multicolumn{5}{c}{ Hasil Uji Liniearitas } \\
\hline & & (Combined) & 4.647 & Signifikansi \\
\hline \multirow{2}{*}{ Penyesuaian Diri * Efikasi Diri } & Between & Liniearity & 69.188 & .000 \\
& Groups & $\begin{array}{c}\text { Deviation from } \\
\text { Limiearity }\end{array}$ & 1.574 & .068 \\
\hline \multirow{2}{*}{$\begin{array}{c}\text { Penyesuaian Diri * Dukungan } \\
\text { Sosial Teman Sebaya }\end{array}$} & Between & (Combined) & 2.738 & .000 \\
& Liniearity & 38.336 & .000 \\
Deviation from & Liniearity & 1.590 & .044
\end{tabular}

Berdasarkan hasil uji asumsi ketiga yaitu uji multikoliniearitas menunjukkan bahwa nilai tolerance sebesar $0,798(>0,10)$ dan nilai VIF sebesar 1,254 $(<10)$. Sehingga 
dapat dikatakan tidak terdapat multikoliniearitas atau tidak adanya hubungan yang liniear antar variabel bebas efikasi diri dan dukungan sosial teman sebaya. Untuk hasil selengkapnya dapat dilihat pada tabel berikut:

\begin{tabular}{|c|c|c|c|c|}
\hline \multicolumn{5}{|c|}{ Hasil Uji Multikoliniearitas } \\
\hline \multirow{2}{*}{ Model } & \multirow{2}{*}{ Signifikansi } & \multicolumn{2}{|c|}{ Collinearity Statistics } & \multirow{2}{*}{ Keterangan } \\
\hline & & Tolerance & VIF & \\
\hline Efikasi Diri & .000 & .798 & 1.254 & $\begin{array}{c}\text { Tidak ada } \\
\text { multikoliniearitas }\end{array}$ \\
\hline $\begin{array}{c}\text { Dukungan Sosial Teman } \\
\text { Sebaya }\end{array}$ & .002 & .798 & 1.254 & $\begin{array}{l}\text { Tidak ada } \\
\text { multikoliniearitas }\end{array}$ \\
\hline
\end{tabular}

a Dependent Variable: Penyesuaian Diri

Berdasarkan uji normalitas, uji liniearitas dan uji multikoliniearitas yang telah dilakukan oleh peneliti diperoleh hasil bahwa data penelitian memiliki distribusi normal, memiliki hubungan yang liniear dan bebas dari gejala multikoliniearitas sehingga dapat dilanjutkan ke tahap berikutnya yaitu uji regresi berganda.

Pada penelitian ini, pengujian hipotesis akan dilakukan dengan menggunakan analisis regresi berganda. Metode analisis regresi berganda digunakan untuk melihat hubungan lebih dari satu variabel bebas dan satu variabel terikat (Santoso, 2005).

Hasil Uji Regresi Berganda Efikasi Diri dan Dukungan Sosial Teman Sebaya Terhadap Penyesuaian Diri

\begin{tabular}{|c|c|c|c|}
\hline $\mathrm{R}$ & $\begin{array}{l}\text { Penyesuarat } \\
\text { R Square }\end{array}$ & Adjusted R Square & $\begin{array}{l}\text { Std. Error of the } \\
\text { Estimate }\end{array}$ \\
\hline 0,605 & 0,367 & 0,357 & 6,265 \\
\hline
\end{tabular}

Berdasarkan tabel di atas, dapat dilihat hubungan yang terjadi antara variabel bebas dan variabel tergantung pada nilai koefisien regresi $(\mathrm{R})$ sebesar 0,605. Koefisien determinasi (R2) yang diperoleh dengan mengkuadratkan nilai R (0,605) sehingga didapatkan hasil R2 sebesar 0,367. Koefisien determinasi menunjukkan besarnya peran atau sumbangan yang dapat diberikan dari variabel bebas terhadap variabel tergantung. Selain itu, didapatkan koefisien determinasi sebesar 0,367 yang berarti diperoleh sumbangan efektif dari variabel efikasi diri dan dukungan sosial teman sebaya terhadap penyesuaian diri sebesar $36,7 \%$. Sementara sumbangan selain dari variabel efikasi diri dan dukungan sosial teman sebaya adalah sebesar $63,3 \%$ dipengaruhi oleh faktor-faktor lain yang tidak diteliti dalam penelitian ini.

Hasil Uji Regresi Berganda Signifikansi Nilai F

\begin{tabular}{lrrrrr} 
& Sum of Squares & df & Mean Square & F & Sig. \\
\hline Regression & 3043.769 & 2 & 1521.884 & 38.776 & .000 \\
\hline Residual & 5259.239 & 134 & 39.248 & & \\
\hline Total & 8303.007 & 136 & & & \\
\hline
\end{tabular}

Pada tabel hasil uji regresi berganda signifikansi nilai

$\mathrm{F}$, diperoleh $\mathrm{F}$ hitung adalah 38,776 dengan taraf signifikansi 0,000. Model regresi dapat digunakan untuk memprediksi penyesuaian diri karena signifikansi berada dibawah 0,05 sehingga dapat dijelaskan bahwa efikasi diri dan dukungan sosial teman sebaya secara bersama-sama berperan terhadap penyesuaian diri.
Berdasarkan hasil uji yang dilakukan menunjukkan bahwa variabel efikasi diri mempunyai pengaruh lebih besar terhadap penyesuaian diri. Variabel efikasi diri memiliki koefisien beta terstandarisasi 0,457 dengan nilai $\mathrm{t}$ sebesar 5,935 dan memiliki taraf signifikansi sebesar 0,000 $(\mathrm{p}<0,05)$ yang berarti efikasi diri berpengaruh secara signfikan terhadap penyesuaian diri. Sedangkan variabel dukungan sosial teman sebaya memiliki koefisien beta terstandarisasi 0,242 dengan nilai $\mathrm{t}$ sebesar 3,141 dan memiliki taraf signifikansi sebesar $0,002(\mathrm{p}<0,05)$ yang berarti dukungan sosial teman sebaya berpengaruh secara signfikan terhadap penyesuaian diri. Untuk hasil selengkapnya dapat dilihat pada tabel di bawah ini:

\begin{tabular}{|c|c|c|c|c|c|c|}
\hline \multirow[b]{3}{*}{ Model } & \multicolumn{6}{|c|}{ Terhadap Penyesuaian Diri } \\
\hline & & \multicolumn{2}{|c|}{$\begin{array}{l}\text { Unstandardized } \\
\text { Coefficients }\end{array}$} & \multicolumn{3}{|l|}{$\begin{array}{l}\text { Standardized } \\
\text { Coefficients }\end{array}$} \\
\hline & & B & Std. Error & Beta & $t$ & Sig. \\
\hline \multirow[t]{4}{*}{1} & (Constant) & 38.714 & 8.965 & & 4.318 & .000 \\
\hline & $\begin{array}{l}\text { Efikasi } \\
\text { Diri }\end{array}$ & .806 & .136 & .457 & 5.935 & .000 \\
\hline & $\begin{array}{l}\text { Dukungan } \\
\text { Sosial }\end{array}$ & & & & & \\
\hline & $\begin{array}{l}\text { Teman } \\
\text { Sebaya }\end{array}$ & .248 & .079 & .242 & 3.141 & .002 \\
\hline
\end{tabular}

\section{PEMBAHASAN DAN KESIMPULAN}

Penelitian ini bertujuan untuk mengetahui peran efikasi diri dan dukungan sosial teman sebaya terhadap penyesuaian diri mahasiswa tahun pertama Program Studi Pendidikan Dokter Fakultas Kedokteran Universitas Udayana. Berdasarkan hasil penelitian yang telah dilakukan dan dianalisis dengan menggunakan teknik analisa regresi ganda, dapat diketahui bahwa pengujian hipotesis adanya peran yang signifikan dari efikasi diri dan dukungan sosial teman sebaya terhadap penyesuaian diri mahasiswa tahun pertama Program Studi Pendidikan Dokter Fakultas Kedokteran Universitas Udayana dapat diterima.

Hal ini dapat dilihat dari nilai koefisien regresi dalam penelitian ini adalah sebesar 0.605 dengan $F$ hitung sebesar 38,776 dengan taraf signifikansi $0,000(\mathrm{p}<0,05)$ menunjukkan bahwa efikasi diri dan dukungan sosial teman sebaya secara bersama-sama berperan terhadap penyesuaian diri.

Koefisien determinasi sebesar 0,367 menunjukkan bahwa kedua variabel bebas yaitu efikasi diri dan dukungan sosial teman sebaya memiliki sumbangan efektif sebesar $36,7 \%$ terhadap variabel tergantung yaitu penyesuaian diri. Berdasarkan koefisien determinasi tersebut maka dapat ditarik kesimpulan bahwa efikasi diri dan dukungan sosial teman sebaya menentukan $36,7 \%$ penyesuaian diri yang dimiliki mahasiswa tahun pertama Program Studi Pendidikan Dokter Fakultas Kedokteran Universitas Udayana, sedangkan 63,3\% dipengaruhi oleh variabel lain yang tidak diteliti dalam penelitian ini. 
Dari hasil koefisien beta terstandarisasi, diketahui bahwa efikasi diri dan dukungan sosial teman sebaya secara mandiri memiliki peran terhadap penyesuaian diri. Variabel efikasi diri memiliki koefisien beta terstandarisasi 0,457 dengan nilai $\mathrm{t}$ 5,935 dan taraf signifikansi $0,000 \quad(\mathrm{p}<0,05)$. Hal tersebut menunjukkan bahwa efikasi diri berpengaruh terhadap penyesuaian diri. Pada variabel dukungan sosial teman sebaya diperoleh koefisien beta terstandarisasi sebesar 0,242 dengan nilai $\mathrm{t} \quad 3,141$ dan taraf signifikansi 0,002 $\quad(\mathrm{p}<0,05)$ menunjukkan bahwa dukungan sosial teman sebaya berpengaruh terhadap penyesuaian diri. Dari hasil koefisien beta terstandarisasi diketahui variabel bebas yang lebih berpengaruh terhadap penyesuaian diri adalah efikasi diri.

Memasuki lingkungan baru, khususnya lingkungan kampus merupakan salah satu perubahan besar pada hidup seseorang. Pada tahun pertama perkuliahan, mahasiswa biasanya akan mengalami berbagai perubahan dan tuntutan. Banyak mahasiswa mengalami perubahan sistem belajar mengajar, serta tuntutan tugas yang lebih sulit, semenjak masuk masa perkuliahan dibandingkan dengan masa SMA. Hal ini menunjukkan bahwa mahasiswa benar-benar mengalami perubahan yang jauh berbeda saat menjalani perkuliahan di perguruan tinggi. Oleh karena adanya berbagai perubahan dan tuntutan yang dialami mahasiswa tahun pertama, maka dari itu kemampuan penyesuaian diri merupakan hal utama yang harus dimiliki oleh mahasiswa. Kemampuan penyesuaian diri mahasiswa pada perkuliahan terutama pada mahasiswa baru yang masih dalam proses mengenali lingkungan dan sistem belajar yang ada, cenderung terkait dengan keyakinan dan kesanggupan diri mahasiswa untuk mengerjakan tugas-tugas yang berorientasi pada hasil yang diharapkan Kemampuan tersebut disebut efikasi diri. Klassen (2004) berpendapat bahwa penyesuaian diri dengan lingkungan akademik dipengaruhi oleh seberapa besar kesanggupan dan keyakinan dirinya untuk mengerjakan tugas dan peran barunya sebagai seorang pelajar di pendidikan tinggi.

Pada deskripsi data penelitian, variabel efikasi diri memiliki mean teoritis sebesar 50 dan mean empiris sebesar 57,55 menunjukkan bahwa subjek memiliki efikasi diri yang tinggi (mean teoritis < mean empiris). Hal ini membuktikan bahwa mahasiswa tahun pertama Program Studi Pendidikan Dokter Fakultas Kedokteran Universitas Udayana memiliki efikasi diri yang tinggi. Dari hasil kategorisasi data efikasi diri menunjukkan 45 orang atau sekitar $32,9 \%$ subjek memiliki efikasi diri sedang, 88 orang atau sekitar 64,2\% subjek memiliki efikasi diri tinggi dan 4 orang atau sekitar 2,9\% subjek memiliki efikasi diri yang sangat tinggi.

Terbentuknya efikasi diri yang tinggi pada mahasiswa tahun pertama Program Studi Pendidikan Dokter Fakultas Kedokteran Universitas Udayana dapat dikaji dari adanya pengaruh keberhasilan mahasiswa ketika memasuki fakultas terfavorit di Universitas Udayana. Mahasiswa yang berhasil masuk fakultas terfavorit mempunyai rasa percaya terhadap kemampuan diri sehingga mampu mendorong seseorang meraih segala sesuatu yang diinginkannya. Hal tersebut sesuai dengan pendapat Bandura (1997) bahwa pengalaman berhasil merupakan sumber efikasi diri yang paling penting. Untuk membentuk efikasi diri, seseorang harus pernah menghadapi tantangan dalam hidupnya. Tantangan tersebut akan mengajarkan individu untuk mengembangkan usaha dan kegigihan. Apabila individu mampu melalui tantangan ini dengan hasil perjuangannya maka hal tersebut akan membawa pengaruh dalam peningkatan efikasi diri. Mahasiswa yang berhasil berjuang untuk masuk ke fakultas favoritnya akan mempengaruhi peningkatan efikasi diri, sehingga hal tersebut akan membantu individu untuk melewati tantangan selanjutnya setelah memasuki fakultas tersebut.

Pada deskripsi data penelitian, variabel dukungan sosial teman sebaya memiliki mean teoritis sebesar 95 dan mean empiris sebesar 115,29 menunjukkan bahwa subjek memiliki dukungan sosial teman sebaya yang tinggi (mean teoritis < mean empiris). Hal ini membuktikan bahwa mahasiswa tahun pertama Program Studi Pendidikan Dokter Fakultas Kedokteran Universitas Udayana memiliki dukungan sosial yang tinggi. Dari hasil kategorisasi data efikasi diri menunjukkan 10 orang atau sekitar 7,3\% subjek memiliki dukungan sosial teman sebaya sedang, 107 orang atau sekitar $78,1 \%$ subjek memiliki dukungan sosial teman sebaya tinggi dan 20 orang atau sekitar 14,6\% subjek memiliki dukungan sosial teman sebaya yang sangat tinggi.

Tingginya dukungan sosial teman sebaya yang diperoleh mahasiswa tahun pertama Program Studi Pendidikan Dokter Fakultas Kedokteran Universitas Udayana dapat dikaji dari tersedianya media yang dapat mempererat hubungan antar mahasiswa seperti adanya SGD (small group discussion), mahasiswa dapat berinteraksi dengan bertukar pikiran mengenai materi perkuliahan dan berdiskusi mengenai berbagai hal lainnya. Selain itu, kegiatan-kegiatan yang melibatkan mahasiswa antar program studi selama tahun pertama perkuliahan dapat membantu mahasiswa menjalin hubungan pertemanan dengan lebih banyak orang sehingga dari hubungan tersebut akan membantu mereka memperoleh afeksi dan belajar berempati. Menurut Santrock (2007), remaja memiliki kebutuhan cukup kuat untuk disukai dan diterima oleh teman sebaya dalam konteks individu maupun kelompok. Ketika mereka merasa diterima oleh teman sebaya maka akan timbul perasaan senang dan sebaliknya ketika mereka merasa diabaikan maka mereka akan merasa tertekan dan cemas. Ketika mahasiswa dapat menjalin hubungan pertemanan yang baik melalui kegiatan SGD (small group discussion) atau kegiatan kemahasiswaan lainnya, maka disana akan terjadi proses pertukaran sosial. Keseimbangan dalam pertukaran sosial akan menghasilkan hubungan interpersonal yang 
memuaskan. Pengalaman akan pertukaran secara timbal balik akan membuat individu lebih percaya bahwa orang lain akan menyediakan bantuan.

Pada deskripsi data penelitian, variabel penyesuaian diri memiliki mean teoritis sebesar 97,5 dan mean empiris sebesar 113,73 menunjukkan bahwa subjek memiliki penyesuaian diri yang tinggi (mean teoritis < mean empiris). Hal ini membuktikan bahwa mahasiswa tahun pertama Program Studi Pendidikan Dokter Fakultas Kedokteran Universitas Udayana memiliki penyesuaian diri yang tinggi. Dari hasil kategorisasi data penyesuaian diri menunjukkan 28 orang atau sekitar $20,5 \%$ subjek memiliki penyesuaian diri sedang, 102 orang atau sekitar $74,4 \%$ subjek memiliki penyesuaian diri tinggi dan 7 orang atau sekitar $5,1 \%$ subjek memiliki penyesuaian diri yang sangat tinggi. Hal ini menunjukkan bahwa mayoritas mahasiswa tahun pertama Program Studi Pendidikan Dokter Fakultas Kedokteran Universitas Udayana memiliki penyesuaian diri yang tinggi.

Berdasarkan hasil penelitian ini diperoleh hasil bahwa efikasi dan dukungan sosial teman sebaya berperan dalam penyesuaian diri mahasiswa. Oleh karena itu, penyesuaian diri yang tinggi pada mahasiswa tahun pertama Program Studi Pendidikan Dokter Fakultas Kedokteran Universitas Udayana dapat terbentuk dari adanya efikasi diri dan dukungan sosial teman sebaya yang tinggi. Menurut Schneider (1964), salah satu faktor yang mempengaruhi penyesuaian diri adalah keadaan psikologis yang sehat. Individu yang memiliki kondisi psikologis yang sehat akan memberikan respon yang selaras dengan dorongan internal maupun tuntutan lingkungannya. Selain itu, individu yang memiliki penyesuaian diri yang tinggi mampu berusaha untuk menyelaraskan berbagai tuntutan yang dihadapi baik dari dalam maupun luar diri individu sehingga tercapai keharmonisan antara dirinya dengan lingkungannya. Hal yang termasuk dalam keadaan psikologis yang sehat diantaranya adalah efikasi diri. Selain efikasi diri, dukungan sosial teman sebaya berperan dalam proses penyesuaian diri. Dukungan yang diberikan oleh teman sebaya seperti dukungan emosional, dukungan berupa materi atau jasa, dukungan informasi dan dukungan jaringan sosial akan membuat individu merasa dicintai, diperhatikan dan memiliki harga diri. Hal tersebut akan menjauhkan individu dari konflik dan frustrasi. Menurut Atwater (1983), proses penyesuaian diri mencakup perubahan dalam diri untuk mencapai hubungan yang memuaskan dengan orang lain dan lingkungan sekitar. Adanya pertukaran sosial antar individu yang terjalin sejak awal akan membuat hubungan interpersonal khususnya dengan teman sebaya menjadi lebih baik.

Berdasarkan hasil analisis tambahan yang dilakukan oleh peneliti yang telah dirangkum pada lampiran 16, diperoleh hasil uji Independent Sample t-Test pada variabel efikasi diri menunjukkan skor probabilitas 0.633 ( $\mathrm{p}>0.05)$.
Hal ini berarti tidak terdapat perbedaan efikasi diri berdasarkan jenis kelamin. Menurut Bandura (1997), efikasi diri tidak berkaitan dengan kecakapan yang dimiliki seseorang, tetapi berkaitan dengan keyakinan individu mengenai hal apa yang dapat dilakukan dengan kecakapan yang ia miliki. Tinggi atau rendahnya efikasi diri mahasiswa tidak dipengaruhi oleh jenis kelamin tetapi dipengaruhi oleh keyakinan yang dimiliki.

Berikutnya adalah hasil uji Independent Sample t-test pada variabel dukungan sosial teman sebaya menunjukkan skor probabilitas 0.539 ( $\mathrm{p}>0.05)$. Hal ini berarti tidak terdapat perbedaan dukungan sosial teman sebaya berdasarkan jenis kelamin. Menurut Santrock (2007), seseorang pada usia remaja akan cenderung mendekatkan diri pada teman-teman yang memiliki rentang usia yang sebaya dengan dirinya. Hal ini menunjukkan bahwa mahasiswa laki-laki atau perempuan mempunyai keinginan yang sama untuk menjalin pertemanan. Selanjutnya hasil uji Independent Sample t-Test pada variabel penyesuaian diri menunjukkan skor probabilitas 0.491 ( $p>$ 0.05). Hal ini berarti tidak terdapat perbedaan penyesuaian diri berdasarkan jenis kelamin. Namun demikian, terdapat penelitian lain yang membahas bahwa terdapat perbedaan penyesuaian diri antara laki-laki dengan perempuan. Menurut Squire (dalam Suhapti, 1995) dan Risveni (2006) penyesuaian diri ternyata berbeda antara laki-laki dan perempuan. Hal ini disebabkan oleh adanya perbedaan perlakuan antara perempuan dan laki-laki dalam masyarakat. Santrock (2003) berpendapat bahwa streotype mengenai jenis kelamin di masyarakat cenderung mengarahkan seseorang pada apa yang diharapkan bukan pada kenyataan yang ada. Laki-laki dengan penyesuaian diri yang baik diharapkan untuk mandiri, agresif, dan berorientasi pada kekuasaan, sementara perempuan diharapkan untuk tergantung pada orang lain. Pada penelitian ini menunjukkan bahwa stereotype yang diharapkan masyarakat tidak selalu sesuai dengan kenyataan. Laki-laki atau perempuan memiliki tingkat penyesuaian yang cenderung tinggi. Hal ini disebabkan oleh beberapa faktor seperti keadaan fisik, perkembangan dan kematangan, keadaan psikologis, keadaan lingkungan dan tingkat religiusitas dan kebudayaan.

Berdasarkan hasil penelitian dan analisis data yang dilakukan, dapat disimpulkan bahwa efikasi diri dan dukungan sosial teman sebaya secara bersama-sama berperan terhadap penyesuaian diri mahasiswa tahun pertama Program Studi Pendidikan Dokter Fakultas Kedokteran Universitas Udayana. Efikasi diri berperan terhadap penyesuaian diri mahasiswa tahun pertama Program Studi Pendidikan Dokter Fakultas Kedokteran Universitas Udayana. Efikasi diri mahasiswa tahun pertama Program Studi Pendidikan Dokter Fakultas Kedokteran Universitas Udayana tergolong tinggi karena berdasarkan kategorisasi 64,2\% subjek memiliki efikasi diri yang tinggi. Dukungan sosial teman sebaya berperan terhadap 
penyesuaian diri mahasiswa tahun pertama Program Studi Pendidikan Dokter Fakultas Kedokteran Universitas Udayana. Dukungan sosial teman sebaya mahasiswa tahun pertama Program Studi Pendidikan Dokter Fakultas Kedokteran Universitas Udayana tergolong tinggi karena berdasarkan kategorisasi $78,1 \%$ subjek memiliki dukungan sosial teman sebaya yang tinggi. Penyesuaian diri mahasiswa tahun pertama Program Studi Pendidikan Dokter Fakultas Kedokteran Universitas Udayana tergolong tinggi karena berdasarkan kategorisasi $74,4 \%$ subjek memiliki penyesuaian diri yang tinggi. Tidak terdapat perbedaan efikasi diri, dukungan sosial teman sebaya dan penyesuaian diri mahasiswa tahun pertama Program Studi Pendidikan Dokter Fakultas Kedokteran Universitas Udayana dilihat berdasarkan jenis kelamin.

Berdasarkan hasil penelitian tersebut dapat diajukan berbagai saran yaitu bagi orangtua diharapkan dapat memberikan perlakuan yang dapat meningkatkan efikasi diri sejak dini dengan cara memberikan tantangan dalam setiap kegiatan sehingga ketika anak memiliki pengalaman berhasil akan membantu proses perkembangan efikasi diri. Memberikan nasihat, saran dan motivasi kepada anak agar lebih mampu menjalani masa tahun pertama perkuliahannya.

Bagi mahasiswa diharapkan untuk tetap bersikap terbuka dengan teman sebaya. Hal ini dapat terwujud dalam tindakan seperti aktif mengikuti kegiatan intra kampus, mengikuti diskusi kelompok mengenai materi perkuliahan ataupun hal yang bersifat pribadi. Selain bersikap terbuka, penting bagi mahasiswa untuk membangun kepekaan, inisiatif dan proaktif untuk menemukan solusi jika menemui kendalam dalam perkuliahan. Mahasiswa diharapkan selalu dapat melakukan manajemen diri yang baik dalam menghadapi tuntutan akademik. Hal ini terwujud dalam tindakan seperti membuat jadwal kegiatan harian sesuai prioritas, membuat tugas tepat waktu, belajar tidak hanya pada saat menjelang ujian, disiplin dan bersikap kritisterhadap kegiatan yang konstruktif dalam memenuhi kebutuhan akademik.

Bagi institusi pendidikan diharapkan dapat menyediakan media untuk mempererat hubungan antar mahasiswa dengan menyediakan fasilitas SGD (small group discussion), menyediakan kegiatan ekstrakurikuler dan pelatihan-pelatihan terkait dengan efikasi diri dan hubungan dengan teman sebaya. Selain itu dosen pembimbing akademik diharapkan untuk selalu peka terhadap permasalahan yang dialami mahasiswa tahun pertama. Dosen pembimbing akademik juga diharapkan dapat memantau perkembangan mahasiswa tahun pertama dan melakukan konseling secara berkala untuk membantu mereka melalui masa transisi dari kehidupan Sekolah Menengah Atas (SMA) menuju kehidupan kampus.

Bagi peneliti selanjutnya diharapkan sampel yang digunakan dalam penelitian ini adalah mahasiswa tahun pertama Program Studi Pendidikan Dokter Fakultas Kedokteran Universitas Udayana. Peneliti yang ingin melakukan penelitian serupa dapat menjaring sampel tidak hanya dari satu program studi saja, tetapi dapat menjaring sampel dari seluruh program studi di Fakultas atau Universitas. Selain itu peneliti yang ingin melakukan penelitian serupa agar dapat memperbesar jumlah responden. Peneliti tidak hanya menggunakan responden dari angkatan tahun pertama, tetapi juga melibatkan angkatan tahun kedua, tahun ketiga dan tahun keempat. Hasil penelitian yang melibatkan seluruh angkatan dapat memberikan gambaran mengenai perbedaan efikasi diri, dukungan sosial teman sebaya dan penyesuaian diri antar angkatan.

Sumbangan efektif dalam penelitian ini sebesar $47,1 \%$ sedangkan sisanya sebanyak $52,9 \%$ dijelaskan oleh faktor lain. Faktor-faktor lain yang tidak diteliti dalam penelitian ini seperti motivasi, tipe kepribadian dan coping strategy dapat dijadikan bahan penelitian selanjutnya yang mungkin memiliki hubungan dan mempengaruhi penyesuaian diri. Peneliti selanjutnya dapat memperkaya data demografi dari subjek seperti melihat asal responden, tempat tinggal responden, pekerjaan orangtua dan IPK terakhir dengan dianalisis secara statistik kuantitatif atau kualitatif.

\section{DAFTAR PUSTAKA}

Abdulghani, H.M. (2008). Stress and depression among medical students: a cross section study at medical college in Saudi Arabia. Pak J med Sci, 24(1), 12-27.

Atwater, E. (1983). Psychology of adjusment: personal growth in a changing world. New Jersey: Prentice-Hall.

Bandura, A. (1997). Self-efficacy the exercise of control. New York: W.H. Freeman and Company.

Effendi, R.W. \& Tjahjono, E. (1999). Hubungan antara perilaku coping dan dukungan sosial dengan kecemasan pada ibu hamil anak pertama. Indonesian Psychology Journal Anima, 14(54), 214-227.

Gunarsa, S.D. \& Gunarsa Y.S. (2000). Psikologi praktis: anak, remaja, dan keluarga. Jakarta: Gunung Mulia.

Hurlock, E.B. (1980). Psikologi perkembangan: suatu pendekatan sepanjang rentang kehidupan. Jakarta: Erlangga.

Klassen, R.M. (2004). A cross cultural investigation of the self efficacy beliefs of South Asian immigrant and anglo Canadian nonimmigrant early adolescents. Journal of Educational Psychology. 96, 731-742.

Maulana, Z.F., Soleha T.U., Saftarina F., \& Siagian .J.M.C. (2014). Perbedaan tingkat stres antara mahasiswa tahun pertama dan tahun kedua di Fakultas Kedokteran Universitas Lampung. ISSN 2337-3776, 154-162.

Muharomi, L.S. (2012). Hubungan antara tingkat kecemasan komunikasi dan konsep diri dengan kemampuan beradaptasi mahasiswa baru. (Skripsi tidak dipublikasikan). Fakultas Ilmu Sosial dan Ilmu Politik Universitas Diponegoro, Semarang. 
Papalia, D. E., Olds, S. W., \& Feldman R. D. (2008). Human development: perkembangan manusia (ed 10). Jakarta: Salemba Humanika.

Risveni, N. (2006). Perbedaan penyesuaian sosial pada mahasiswa baru ditinjau dari jenis kelamin. (Skripsi tidak dipublikasikan). Fakultas Psikologi Universitas Islam Indonesia. Yogyakarta.

Rustika, I.M. (2014). Faktor-faktor yang mempengaruhi prestasi akademik pada remaja. (Disertasi tidak dipublikasikan). Fakultas Psikologi Universitas Gadjah Mada, Yogyakarta.

Santrock, JW. (2003). Adolescence: perkembangan remaja (ed.6). Jakarta: Erlangga.

Santrock, J.W. (2007). Remaja. Jakarta: Erlangga.

Sarafino, E. P., \& Smith T. W . (2010). Health psychology biopsychosocial interactions (7 ed). New York: John Wiley $\&$ Sons, Inc.

Sasmita, I.A.H.D. (2014). Penyesuaian diri mahasiswa tahun pertama Program Studi Pendidikan Dokter Fakultas Kedokteran Universitas Udayana: sebuah studi pendahuluan. Denpasar: Fakultas Kedokteran Universitas Udayana.

Schneiders. A.A. (1964). Personal adjustment and mental health. New York: Holt, Rinehart, and Winston.

Shah M., Hasan S., Malik S., \& Sreeramareddy C.T. (2010). Perceived stress, sources and severity of stress among medical undergraduates in a Pakistani medical school. BMC Medical Education, 10(1), 2.

Smet, B. (1994). Psikologi kesehatan. Jakarta: PT. Gramedia Widiarsana Indonesia.

Suganda, K.D. (2013). Tingkat stres pada mahasiswa tahun pertama Fakultas Kedokteran Universitas Sumatera Utara angkatan 2013. (Skripsi tidak dipublikasikan), Fakultas Kedokteran Universitas Sumatera Utara, Medan.

Sugiyono, (2013). Metode penelitian kuantitatif, kualitatif dan r\&d. Bandung: Alfabeta.

Suhapti, R. (1995). Gender dan permasalahannya. Buletin Psikologi, 44-50.

Taylor, S. E., Peplau, L. A., \& Sears, D. O. (2000). Social psychology (ed 10). New Jerssey: Prentice-Hall. 